\title{
進化型多目的最適化における探索履歴を活用した 局所解脱出と集中探索メカニズム
}

\section{Escaping from Local Optima and Convergence Mechanisms Based on Search History in Evolutionary Multi-criterion Optimization}

\author{
左文字 響室蘭工業大学大学院 情報電子工学系専攻 \\ Hibiki Samonji Division of Information and Electronic Engineering, Muroran Institute of Technology \\ 15043026@mm.muroran-it.ac.jp \\ 渡邊 真也 \\ 室蘭工業大学大学院しくみ情報系領域 \\ College of Information and Systems, Muroran Institute of Technology \\ sin@csse.muroran-it.ac.jp
}

keywords: evolutionary multi-criterion optimization, local search, search history

\begin{abstract}
Summary
In this paper, a new local search approach using a search history in evolutionary multi-criterion optimization (EMO) is proposed. This approach was designed by two opposite mechanisms (escaping from local optima and convergence search) and assumed to incorporate these into an usual EMO algorithm for strengthening its search ability. The main feature of this approach is to perform a high efficient search by changing these mechanisms according to the search condition. If the search situation seems to be stagnated, escape mechanism would be applied for shifting search point from this one to another one. On the other hand, if it observes no sign of the improvement of solutions after repeating this escape mechanism for a fixed period, convergence mechanism is applied to improve the quality of solution through an intensive local search. This paper presents a new approach, called "escaping from local optima and convergence mechanisms based on search history - SPLASH -".

Experimental results showed the effectiveness of SPLASH and the workings of SPLASH's two mechanisms using WFG test suites.
\end{abstract}

\section{1.はじめ に}

近年, 進化型多目的最適化 (Evolutionary Multi-criterion Optimization, EMO) の関連研究が活発に行われており, 大きな進歩を見せている [Coello 04, Deb 01]. 中でも， 多目的進化型アルゴリズム (Multi-objective Evolutionary Algorithm, MOEA)に局所探索手法を組み合わせ，解の 収束性能の向上を図るアプローチは数多く提案され, 大き な成果を挙げている [Ishibuchi 98, Knowles 00, Martínez 13].

一般にこれらのアプローチでは, 遺伝的アルゴリズム (Genetic Algorithm, GA) などの進化型アルゴリズムで グローバルな探索を行い, 何らかの近傍探索操作により 局所探索を行っている場合が多い [Ishibuchi 98, Knowles 00, Martínez 13]. 一方, 局所解に陥った場合に対する明 示的な解決策をメカニズムに組み込んでいるものはごく 一部に限定されている.

そこで本稿では, MOEA の探索性能を強化させること を目的とした, 新たな局所探索メカニズム SPLASH(eScaPing from Local optimA and convergence mechanisms based on Search History) を提案する. 提案手法は, 探索履歴を 活用した局所解脱出及び集中探索という相異なる 2 つ メカニズムに基づくものであり，未探索領域への探索と 有望領域への集中的な探索を組み合わせたものとなって いる.

本手法では，探索過程で得られた実数情報を離散化し 保存することで探索履歴情報の効率的な利用を実現して いる. 局所解脱出メカニズムでは, 探索履歴情報全体を 基に大まかな探索の様子を読み取り，未探索の領域を推 定し，局所解から脱出することを試みる. 一方，集中探 索メカニズムでは, 探索履歴情報の一部を用いて, 有望 な探索領域を推定し集中的な探査を行う.

それぞれのメカニズムにおける計算量は，通常の遺伝 的操作において費やすものと等しく設定しており，通常 の操作の代替として用いる場合, 世代あたりの計算量に 変化は生じない.

提案手法の有効性の検証のため, 代表的な MOEA の一 つである MOEA/D-DE(MOEA based on Decomposition with Differential Evolution)[Li 09]に提案手法を組み込 
んだアルゴリズムを利用し，代表的なテスト問題である WFG Test Suites[Huband 05] に対して代表的な解評価指 標を用いた数值実験及び探索の推移情報から提案する 2 つのメカニズムの有効性・妥当性の検証を行った.

以下，本稿における構成について述べる．まず 2 章で は, 多目的最適化, 多目的最適化問題並びに多目的進化 型アルゴリズムの一つである MOEA/D-DE について概 説する. 3 章ではこれまでに行われてきた関連研究に関 して述べ，4 章では提案する 2 つの局所探索メカニズム の詳細について説明する．5 章において提案手法の検証 実験を行い，6章にまとめを述べる.

\section{2. 多目的最適化}

ここでは多目的最適化問題とパレート最適解の一般 的な定義について述べた後，代表的な多目的進化型アル ゴリズムについて，本論文の数值実験において使用した MOEA/D-DE[Li 09] について述べる.

\section{$2 \cdot 1$ 多目的最適化問題}

多目的最適化問題とは, 複数個の目的関数を与えられ た制約条件のもとで最小化する問題である．多目的最適 化問題は以下のような式で表される [Deb 01].

$$
\begin{array}{lll}
\min & f_{m}(\boldsymbol{x}) & (m=1,2, \ldots, M) \\
\text { s.t. } & g_{j}(\boldsymbol{x}) \leq 0 & (j=1,2, \ldots, J) \\
& h_{k}(\boldsymbol{x})=0 & (k=1,2, \ldots, K) \\
& \boldsymbol{x} \in S &
\end{array}
$$

解空間 $S$ において, $J$ 個の不等式制約条件 $g_{j}, K$ 個の 等式制約条件 $h_{k}$ によって定義される実行可能領域 $F \subseteq S$ のもとで, $M$ 種類の目的関数 $f_{m}$ を最小化する設計変数 $\boldsymbol{x}$ ( $\boldsymbol{x}$ は $n$ 次元ベクトル) を求める.

一般に多目的最適化問題では，目的関数間にトレード オフの関係が存在するため, ある目的関数の值を改善す るためには，少なくとも他の 1 つの目的関数の值を改悪 せざるを得ないような解を求めていく．このような解の ことをパレート最適解 (Pareto Optimal Solutions) と呼ぶ. 全ての目的が最小化であると仮定して $, x, y \in F$ に対して

$\forall i \in\{1,2, \ldots, M\}: f_{m}(\boldsymbol{x}) \leq f_{m}(\boldsymbol{y}) \wedge \exists m \in$

$$
\{1,2, \ldots, M\}: f_{m}(\boldsymbol{x})<f_{m}(\boldsymbol{y})
$$

を満たすとき， $\boldsymbol{x}$ は $\boldsymbol{y}$ を支配するといい， $\boldsymbol{x}$ が $\boldsymbol{y}$ を優越 していることを示す。 また $\boldsymbol{x}$ を支配する他の解が存在し ないとき, $\boldsymbol{x}$ をパレート最適解という. 多目的最適化問題 では, 全ての目的関数 $f_{m}(\boldsymbol{x})$ において最良の值となるよ うな唯一の完全最適解が存在しないため, パレート最適 解集合全体を求めることが第 1 の目標となっている．た だし，対象問題が設計変数が実数值などの連続值で構成 される関数最適化問題の場合，パレート解は無限に存在
し, パレート最適解を特定することは原理的に不可能で ある，そのため，パレート最適解全体をより高精度に近 似できる集合を求めることがその目的となる [金田 13].

\section{$2 \cdot 2$ 多目的進化型アルゴリズム}

多目的最適化に進化計算の概念を応用した多目的進化 型アルゴリズムは，複数のパレート解を同時に導出する ことが可能であり, 多目的最適化問題に非常に有効な手法 である [Deb 01]. 以下では, 代表的な多目的進化型アル ゴリズムの一つである, MOEA/D-DEについて説明する.

\section{$\S 1$ MOEA/D-DE}

MOEA/D-DE は，交叉法に SBX[Deb 95](Simulated Binary Crossover) を用いる MOEA/D[Zhang 07] に対し て差分進化 (Differential Evolution, DE) の遺伝的操作を 用いるなど，いくつかの改良を加えたアルゴリズムであ る [Li 09]. 探索は一様な重みべクトルに基づくスカラー 化関数によって複数の部分問題に分割して行われ，本稿 では, 文献 [Zhang 07] に示されるスカラー化関数のうち, 式 (3) で定義される Tchebycheff 関数を採用した.

$g^{t e}\left(\boldsymbol{x} \mid \lambda, z^{*}\right)=\max _{1 \leq i \leq m}\left\{\lambda_{i}\left|f_{i}(\boldsymbol{x})-z_{i}^{*}\right|\right\}$

ここで, $\lambda$ はスカラー化関数 $g(\boldsymbol{x})$ に対応する重みベクト ルであり, 目的関数空間における探索方向を決定する. $\boldsymbol{\lambda}=$ $\left(\lambda_{1}, \ldots, \lambda_{M}\right)^{T}$ は $\lambda_{i} \geq 0(i=1, \ldots, M), \sum_{i=1}^{M} \lambda_{i}=1$ で定 義される. 例えば, 2 目的の目的空間を 11 方向に分割する 場合, $\boldsymbol{\lambda}$ は $\lambda_{1}=\{0,1\}, \lambda_{2}=\{0.1,0.9\}, \ldots, \lambda_{10}=\{0.9,0.1\}, \lambda_{11}=$ $\{1,0\}$ となる. また, $z^{*}$ は獲得した理想点を意味してお り, 最小化問題の場合には探索点 $\boldsymbol{x} \in \Omega$ のうち各目的に おける最小值 $z_{i}^{*}=\min \left\{f_{i}(\boldsymbol{x}) \mid \boldsymbol{x} \in \Omega\right\}(i=1,2, \ldots, m)$ と するのが一般的である，ここで， $\Omega$ は最適化中に生成し た解集合である。

MOEA/D-DE のアルゴリズムを以下に示す。以下，対 象問題は最小化問題と仮定する.

step1. 初期化

step1-1. 近傍の決定

重みベクトル $\boldsymbol{\lambda}^{1}, \ldots, \boldsymbol{\lambda}^{N}$ に対して, 全ての組合 せでユークリッド距離を求め, 各重みベクトルに 対して $T$ 個の近傍 $\boldsymbol{B}(i)=\left\{i_{1}, \ldots, i_{T}\right\}$ を定義.

step1-2. 初期個体の生成 初期個体 $\boldsymbol{x}^{1}, \ldots, \boldsymbol{x}^{N}$ を生成し, 評価。

step1-3. 初期理想点の決定

獲得した理想点 $\boldsymbol{z}^{*}=\left(z_{1}^{*}, \ldots, z_{m}^{*}\right)^{T}\left(z_{i}^{*}=\min \left\{f_{i}\right\}\right)$ を設定.

\section{step2. 更新}

$i=1, \ldots, N$ の範囲で行う.

step2-1. 更新 · 選択範囲の決定

$[0,1]$ の一様乱数を用いて, 以下の式で更新・選 
択範囲を決定.

$\boldsymbol{P}= \begin{cases}\boldsymbol{B}(i) & \text { if } \text { rand }<\delta \\ \{1, \ldots, N\} & \text { otherwise }\end{cases}$

step2-2. 交叉

$r_{1}=i$ とし, $\boldsymbol{P}$ からランダムで重複しない $r_{2}, r_{3}$ を選択. $\boldsymbol{x}^{r_{1}}, \boldsymbol{x}^{r_{2}}, \boldsymbol{x}^{r_{3}}$ から DE の遺伝的操作に より子個体 $\overline{\boldsymbol{y}}$ を生成. $\overline{\boldsymbol{y}}$ が設計変数の領域外に あった場合, 該当の設計変数をランダムな值で 置き換える.

step2-3. 突然変異

$\overline{\boldsymbol{y}}$ に Polynomial Mutation[Deb 96] を適用し, $\boldsymbol{y}$ を生成.

\section{step2-4. 理想点の更新}

$z_{j}^{*}<f_{j}(\boldsymbol{y})$ の場合, $z_{j}^{*}=f_{j}(\boldsymbol{y})(j=1, \ldots, m)$ と する.

\section{step2-5. 解の更新}

更新カウンタ $c=0$ とし, 下記の 1)-3) を実行す る.

1) $c=n_{r}$ もしくは $\boldsymbol{P}$ が空の場合, step3 へ進む. そうでなければ, $\boldsymbol{P}$ からランダムで $j$ を選択.

2) $g\left(\boldsymbol{y} \mid \lambda^{j}, \boldsymbol{z}\right) \leq g\left(\boldsymbol{x}^{j} \mid \lambda^{j}, \boldsymbol{z}\right)$ なら, $\boldsymbol{x}^{j}=\boldsymbol{y}$ とお

き, $c=c+1$ とする.

3) $\boldsymbol{P}$ から $j$ を削除し，1）に戻る.

\section{step3. 終了判定}

終了条件を満たしていれば終了。そうでなければ， step2 へ戻る.

step2-2 の DE の遺伝的操作によって得られる子個体 $\overline{\boldsymbol{y}}$ は, (4) によって計算される.ここで $C R$ は交叉率で, $F$ はスケーリングパラメータである.

$\bar{y}_{k}= \begin{cases}x_{k}^{r_{1}}+F \times\left(x_{k}^{r_{2}}-x_{k}^{r_{3}}\right) & \text { if rand }<C R \\ x_{k}^{r_{1}} & \text { otherwise }\end{cases}$

また, step2-3 の突然変異によって得られる子個体 $\boldsymbol{y}$ は, 式 (5), (6) によって計算される. 式 (5) 中の $b_{k}, a_{k}$ はそ れぞれ設計変数の上限值と下限值を, $p_{m}$ は突然変異率 を表す.また，(6) 中の rand は $[0,1]$ の一様乱数で, $\eta$ は 分布指数となっている.

$y_{k}= \begin{cases}\bar{y}_{k}+\sigma_{k} \times\left(b_{k}-a_{k}\right) & \text { if rand }<p_{m} \\ \bar{y}_{k} & \text { otherwise }\end{cases}$

$\sigma_{k}= \begin{cases}(2 \times \text { rand })^{\frac{1}{\eta+1}}-1 & \text { if rand }<0.5 \\ 1-(2-2 \times \text { rand })^{\frac{1}{\eta+1}} & \text { otherwise }\end{cases}$

以上のように MOEA/D-DE は従来の MOEA/D を改良 したものとなっており, 先行研究により従来の MOEA/D に比べ多くの問題で優れた性能を示すことが分かっている.

\section{3. 先 行 研究}

これまで，進化計算に局所探索を組み合わせたアルゴ リズムは Memetic Algorithm(MA)[Moscato 99] と呼ば れ，広く研究されてきた。多目的最適化の枠組みにおい ても MA を多目的に拡張した MOMA(Multi-Objective Memetic Algorithm) は多くの手法が提案されている. 多 目的最適化の場合，複数の基準を同時に考慮しなければ ならないため, 局所探索で生成した近傍解と元の解の優 劣がつきにくいという問題点を持つ. MOGLS[Ishibuchi 98] をはじめとしたいくつかの手法は Weighted Sum 関 数や Tchebycheff といったスカラー化関数を利用した単 目的化を行うことでこの問題に対応している.

これらの手法における局所探索の主な役割として, 解 探索の促進が考えられる. 一方で局所的な解生成は局所 解への収束の恐れがあり, 何らかの局所解脱出メカニズ ムが必要である．局所解脱出としてタブー探索法を組み 込んだ MOEA/D[Alhindi 14] などが提案されているもの の, 多目的の連続問題に対して局所解脱出メカニズムを 明示的に有する MOMA に関する研究事例は非常に限ら れている.

また，擬似焼きなまし法 (Simulated Annealing, SA) や タブー探索法 (Tabu Search, TS) といった, 局所解脱出機 構が暗に組み込まれている単目的最適化手法を多目的に 応用した研究 [Bandyopadhyay 08, Jaeggi 08] が提案され ているものの, これらの手法は局所解からの脱出を実現 するために解の改悪を一時的に許容するアルゴリズムと なっている.

単目的の局所解脱出法としては, いくつかの興味深い 研究が存在する. Hornbyによる ALPS(The Age-Layered Population Structure)[Hornby 06] では，各個体毎に，親 として使用された世代数の概念 (Age) を導入し, 初期解 あるいは優秀でないと考えられる解である Age0 の個体 をランダムに再生成することで局所収束の回避及び局所 解からの脱出を図っている.

また, Barbulescu らは, 解の表現型によって局所解が異 なることに着目し，グレイコードによる解表現を「Shifting」によって適宜変更させることで局所解の脱出を図る 手法を提案している [Barbulescu 00]. この手法は前述の ALPS などと比較して, 探索の改悪を許容しないという 点で異なる。

探索履歴を利用した手法としては，いくつかの有望な 個体をアーカイブに保持しておき，交叉相手として用い る手法は広く行われているほか, これまでに変異した遺 伝子（設計変数）の回数を保持し，その值から変異させ るべき変数を推定する手法 [堀野 12] などが存在する.

一方, 本論文で提案する SPLASH では, 既存の MOEA に組み込んで利用する実装を想定しており，近傍探索と 局所解からの脱出の両方を適応的に切り替える仕様となっ ている点が既存のものとは大きく異なっている．また探 
索履歴情報から解の探索情報を近似的に推定し, 次の探 索戦略を決定している点でもこれらの手法とは異なって いる.

\section{4. 提 案 手 法}

本論文で提案する提案手法 (SPLASH) は，探索履歴を 利用した 2 つのカニズムで構成される。ここでは，提 案手法の全体像について述べた後, 各メカニズムで使用 する探索履歴の保存方法について説明し，提案する局所 解脱出メカニズム及び集中探索メカニズムについて詳細 な説明を行う.

\section{$4 \cdot 1$ 概 要}

SPLASH は, 探索履歴に基づく局所解脱出メカニズム 及び集中探索メカニズムで構成される．探索履歴には最 適化の過程で得られた子個体の設計変数情報を離散化し た情報が保存されており，各メカニズムはこの情報を活用 し未探索領域もしくは有望領域への探索を実現している.

局所解脱出メカニズムは，停滞している個体の設計変 数の一部を強制的に未探索の領域に置き換えており，局 所解に陥りにくい探索の実現を目指すものである.

一方, 集中探索メカニズムでは, 局所解脱出メカニズ ムの適用後も停滞が続く個体に対して，既に良好な個体 であると判断し，設計変数の一部を有望領域に置き換え， 解の洗練化を行う.

これらのメカニズムは, MOEA と組み合わせて実装す ることを想定しており，アルゴリズムの高品質化，効率化 の手助けとなることを期待している．提案手法を MOEA に組み込んだ場合のフローチャートを図 1 に示す. 図中 の状態判定では, 探索の状態に基づき遺伝的操作, 局所 解脱出メカニズム, 集中探索メカニズムのどれを実行す るかを判定している. 提案手法を組み込む MOEA として MOEA/D を用いた場合，各部分問題に属する個体が $K$ 世代連続で更新されていなかった場合に局所解脱出メカ ニズムに入り，さらに $K$ 世代連続で更新されていなかっ た場合 (つまり， $2 K$ 世代連続で更新されていない場合), 集中探索メカニズムに入る，そこからさらに $K$ 世代連続 で更新されていなかった場合 (つまり， $3 K$ 世代連続で更 新されていない場合), 遺伝的操作に戻る. なお, 提案す る 2 つのメカニズムは遺伝的操作の代わりとして適用す るメカニズムであり，2·2 節における step2-1, step2-2 にあたる。

SPLASH は，実数值問題に対して適用することを想定 しており，実数值情報を離散化したものを履歴情報として 保存している．以下，履歴情報の保存方法及び SPLASH のメカニズムの詳細を述べる.

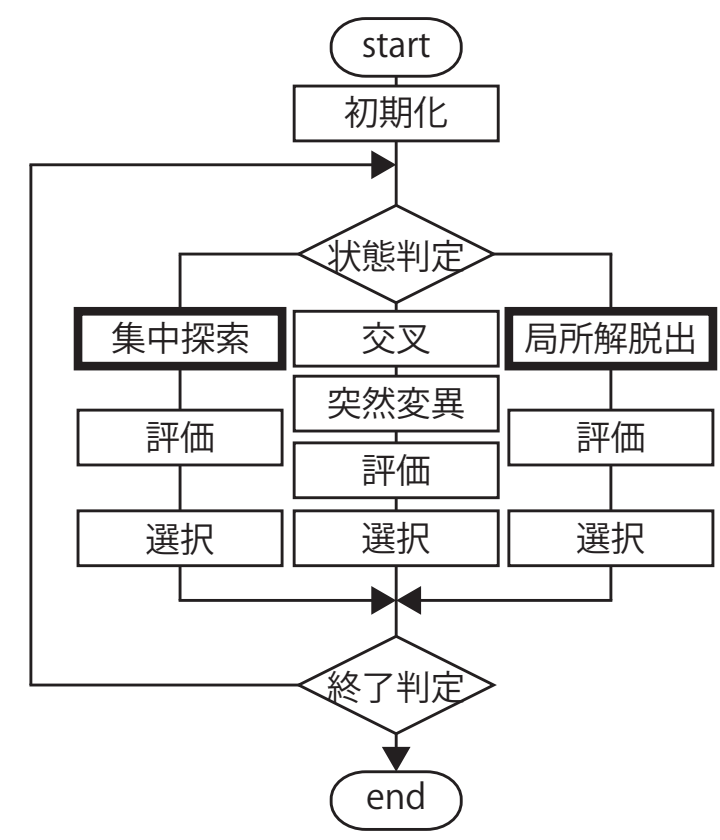

図 1 フローチャート

\section{$4 \cdot 2$ 探索履歴の保存}

2 つのメカニズムが使用する探索履歴の保存方法につ いて説明する．本稿では文献 [Jaeggi 08] で紹介されてい る Long Term Memory(LTM) の概念を用いた近似的な探 索履歴の保存を行う. 具体的には, 各設計変数を $D$ 個の 領域に等分割し, それらの領域に含まれる子個体の数を カウントした值を履歴情報として保存している.

図 2 に，履歴保存の概念図を示す。図 2 の例では，設 計変数の上限 1.0 , 下限 0.0 の問題に対し, $D=5$ として 変数領域を 5 つに分割しており, 領域 1 は 1.0 から 0.8 , 領域 2 は 0.8 から 0.6 , 領域 3 は 0.6 から 0.4 , 領域 4 は 0.4 から 0.2 , 領域 5 は 0.2 から 0.0 の範囲の設計変数 がカウントされる. よって, $\{0.53,0.02,0.9,1.0,0.31\}$ の 変数值をもつ個体のそれぞれの属する領域は $3,5,1,1,4$ となる.このカウント操作を繰り返すことで, 探索の中 で集中的に探索された部分は数值が大きくなり，未探索 の領域は数值が小さいままとなる，本稿では，メモリを MOEA/D-DEにおける部分問題毎に定義し, それぞれ近 傍個体のカウントを行うよう設定した.

\section{$4 \cdot 3$ 局所解脱出メカニズム}

本メカニズムは, 探索履歴に基づき未探索の領域を探 索させることで, 局所解から脱出しやすい探索の実現を 図る. 本手法では, MOEA の探索過程で個体毎に停滞時 間 $k$ を記憶し, 探索の停帯度合いの基準とした。 $k$ は世代 毎に解が更新されなかった場合に +1 ずつ増加させ，探 索過程において一定世代 ( $K$ 世代) 更新されない個体 (つ まり $k>K$ となる個体) に対して本メカニズムを適用す る. なお，更新が行われた場合は $k=0$ にリセットする ものとする。 


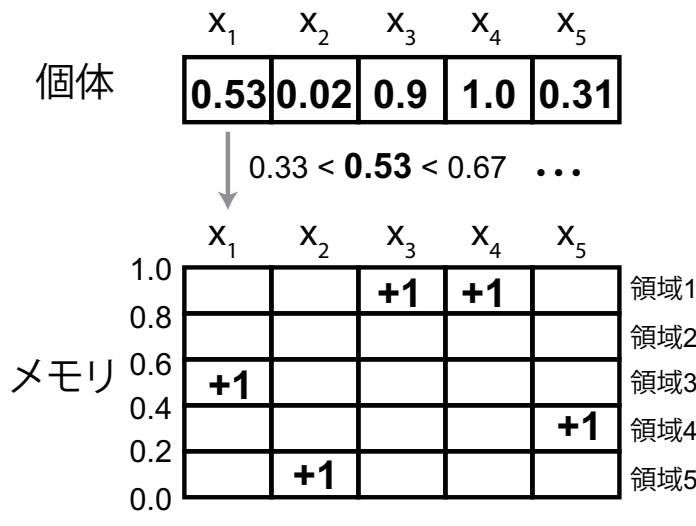

図 2 履歴保存の概念図
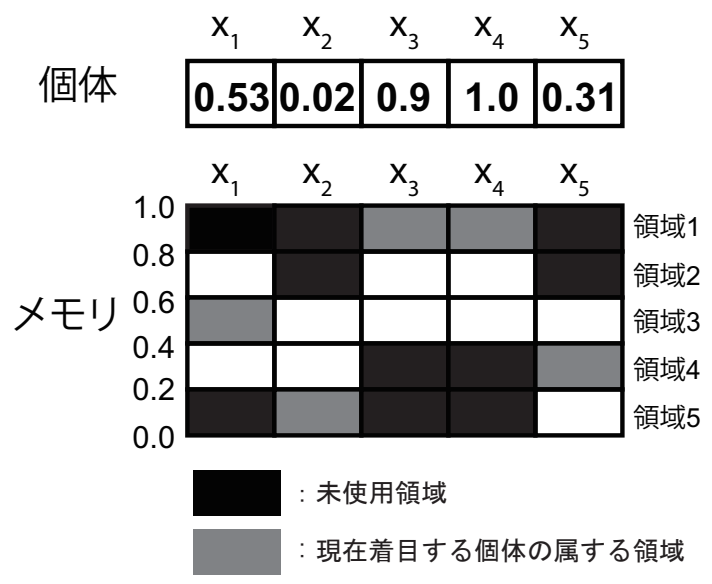

図 3 集中探索メカニズムで使用するメモリ領域

以下にメカニズムの流れを示す。ここでは，前述のメモ リを $\boldsymbol{M}$ とし，その要素を $m_{i j}(i=1, \ldots, D, j=1, \ldots, n)$ とした ( $D$ はメモリの離散化数で, $n$ は設計変数数).

\section{step1. 更新範囲の決定}

$[0,1]$ の一様乱数を用いて, 以下の式で更新範囲を 決定.

$\boldsymbol{P}= \begin{cases}\boldsymbol{B}(i) & \text { if } \text { rand }<\delta \\ \{1, \ldots, N\} & \text { otherwise }\end{cases}$

step2. 変異させる設計変数の決定

着目している個体 $\boldsymbol{x}$ の設計変数のうち, ランダムに 重複しない任意の複数個を選択.

step3. メモリの值の反転

$\boldsymbol{M}=m_{j}^{\text {worst }}-m_{i j}(i=1, \ldots, D, j=1, \ldots, n)$ によ

り求める.ここで, $m_{j}^{\text {worst }}$ は $M$ の $j$ 列目における 最大值である。

step4. 変化量の決定

$M$ の各列にルーレット選択を適用し, 決定された要 素の範囲からランダムな值を決定する。ここで得ら れた乱数べクトルを $\boldsymbol{y}$ とおく.

step5. 新個体の生成 $\boldsymbol{x}$ のうち, step2 で求めた設計変数を $\boldsymbol{y}$ の要素で置

き換え, 新個体 $\boldsymbol{x}^{\prime}$ を生成する.

\section{step6. 更新}

更新カウンタ $c=0$ とし，下記の 1)-3) を実行する. 1) $c=n_{r}$ もしくは $\boldsymbol{P}$ が空の場合, 終了. そうでな ければ, $\boldsymbol{P}$ からランダムでインデックス $p$ を選択.

2) $g\left(\boldsymbol{x}^{\prime} \mid \lambda^{p}, \boldsymbol{z}\right) \leq g\left(\boldsymbol{x}^{p} \mid \lambda^{p}, \boldsymbol{z}\right)$ なら, $\boldsymbol{x}^{p}=\boldsymbol{y}$ とおき, $c=c+1$ とする.

3) $\boldsymbol{P}$ から $p$ を削除し，1) に戻る.

なお，本論文における実験では step2 における変数の 選択方法を変数毎に $1 /$ 設計変数数 の確率で選択する方 法を用いた。ただし，変数が 1 つも選択されなかった場 合には, ランダムに 1 つの変数を強制的に選択する.

\section{4 集中探索メカニズム}

本メカニズムは，探索履歴に基づき有望と見込まれる 領域を徹底探索させることで，解の洗練を図る．基本的 には局所解脱出メカニズムと同じだが，探索履歴情報は 現在着目している個体を中心とした限られた情報のみを 用いる. 図3に, 集中探索に使用するメモリ領域の概念図 を示す. 図3では, 5 分割のメモリに対して, 現在着目す る個体の属する領域を含んだ 3 つの連続した領域のみを 使用する。限定された領域のみを利用することで,「これ までの全ての探索済み領域で良好な領域」ではなく,「現 個体に近い良好な近傍解」の探索を図る.

以下にメカニズムの流れを示す.ここでは, 集中探索で 使用するメモリ領域 (図 3 のメモリにおける白及びグレー の領域) を $\boldsymbol{M}^{\prime}$ とし，その要素を $m_{i j}(i=1, \ldots, D j=$ $1, \ldots, n)$ とした $(D$ は使用するメモリ領域数であり, $n$ は 設計変数の数を表す).

\section{step1. 更新 · 選択範囲の決定}

$[0,1]$ の一様乱数を用いて, 以下の式で更新・選択範 囲を決定.

$$
\boldsymbol{P}= \begin{cases}\boldsymbol{B}(i) & \text { if } \text { rand }<\delta \\ \{1, \ldots, N\} & \text { otherwise }\end{cases}
$$

step2. 変異させる設計变数の決定

着目している個体 $\boldsymbol{x}$ の設計変数のうち, ランダムに 重複しない任意の複数個を選択.

\section{step3. 変化量の決定}

$M^{\prime}$ の各列にルーレット選択を適用し, 決定された 要素の範囲からランダムな值を決定する. 得られた 乱数ベクトルを $\boldsymbol{y}$ とおく.

step4. 新個体の生成

$\boldsymbol{x}$ のうち, step 2 で求めた設計変数を $\boldsymbol{y}$ の要素で置 き換え, 新個体 $\boldsymbol{x}^{\prime}$ を生成する.

step5. 更新

更新カウンタ $c=0$ とし，下記の 1)-3) を実行する. 1) $c=n_{r}$ もしくは $\boldsymbol{P}$ が空の場合, 終了. そうでな 
ければ，Pからランダムでインデックス $p$ を選択.

2) $g\left(\boldsymbol{x}^{\prime} \mid \lambda^{p}, \boldsymbol{z}\right) \leq g\left(\boldsymbol{x}^{p} \mid \lambda^{p}, \boldsymbol{z}\right)$ なら, $\boldsymbol{x}^{p}=\boldsymbol{y}$ とおき, $c=c+1$ とする.

3) $\boldsymbol{P}$ から $p$ を削除し，1)に戻る.

step 2 における変数の選択方法は局所解脱出メカニズ ムと同様である.

\section{5. 数 值 実 験}

提案手法の有効性の検証のため, WFG Test Suites[Huband 05]を用いた 3 つの数值実験を行った. 実験 1 では, 提案 する SPLASH を MOEA/D-DE に組み込んだ場合の性能 の検証を行った。実験 2 では，提案する脱出メカニズム と集中メカニズムそれぞれの有効性の検証を行った。実 験 3 では, SPLASH のパラメータである D 及び K を変 更した場合の性能の変化について検証した。

本章では，はじめに実験 $1 ， 2 ， 3$ で共通となるアルゴ リズム及び問題設定, 評価指標, 対象問題について説明 した後，それぞれの実験結果について述べる.

\section{$5 \cdot 1$ 設定パラメータ}

本実験で使用した設定パラメータを示す.

MOEA/D-DEに関するパラメータは, 近傍サイズ $T=$ 20, メイティング及び選択を近傍内で行う確率 $\delta=0.9$, 個 体の更新数 $n_{r}=2$, 重みベクトルの分割数 $H=199(M=$ 2), $6(M=5), 4(M=8)$ と設定し, $H$ の值に対応して個 体数は $N=200(M=2), 210(M=5), 330(M=8)$ と なる.

また，遺伝的操作に関するパラメータは，交叉に用い られるスケーリング $F=0.5$, 交叉率 $C R=1.0$, 突然変 異率 $M R=1 /$ 設計変数数, Polynomial Mutation におけ る分布指数 $\eta=20$ である.

SPLASH に関するパラメータは, メモリの領域分割数 $D=50$ (要素数は $D n$ 個となる) で，集中探索ではそのう ち 10 個の領域 (要素数は $10 n$ 個となる) を用い, 変異率 は 1 /設計変数数(ただし, 最低でも 1 つの変数を変異) と した. 局所解脱出, 集中探索の適用世代数 $K=5$ とした. 本実験では終了条件は 100,000 関数評価とし，30 試行 の平均值を比較する.

\section{$5 \cdot 2$ 評 価 指 標}

解評価には Zitzler らによる Hypervolume（HV）[Zitzler 98] を用いた. Hypervolume は, 図 4 に示すように ある設定された参照点から，得られた解集合が支配する 目的関数空間上での体積を評価值とするものであり, HV 值が大きいほど優れた解集合であることを示す．解集合 の支配する空間を評価值としているため，解集合の収束 性，多様性及び分散具合を総合的に評価する評価手法と 言える。

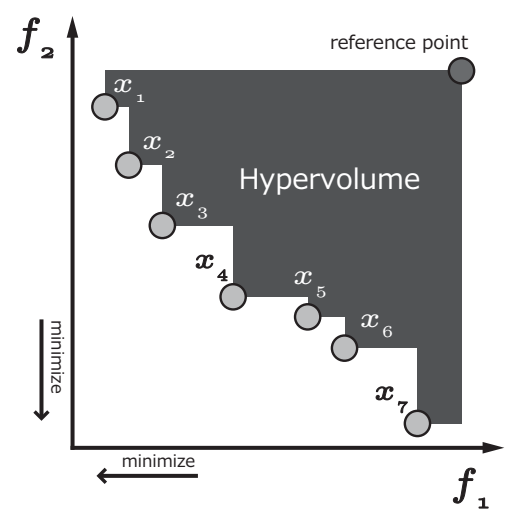

図 4 Hypervolume の概念図

本実験では $f_{m}^{\prime}(\boldsymbol{x})=f_{m}(\boldsymbol{x}) / 2 m(m=0, \ldots, M)$ のよ うに各目的のスケールを正規化した解集合に対して適 用した。また，本実験において基準となる参照点 $\boldsymbol{r}$ は, $\boldsymbol{r}=\{1.5, \ldots, 1.5\}$ と設定した.

\section{$5 \cdot 3$ 対 象 問 題}

対象問題はWFG Test Suites を用いた.WFG は9 個の ベンチマーク関数から構成されている, 目的数, 設計変数 数を任意に変更可能なテスト問題である. 関数の詳細につ いては, 文献 [Huband 05] に示されている通りである. 本 実験では, 設計変数数 $n=20$, 位置変数数 $k=2(M-1)$, 距離変数数 $l=n-k$ とした ( $M$ :目的数). ただし, WFG3 においては，3 目的以上の場合に縮退した 1 次元の解集 合の他に想定外の解の導出が確認されており, その対策 のために文献 [Ishibuchi 16] に示す制約を付与している. WFG の特徵を表 1 に示す.

\section{4 実 験 1}

実験 1 では, 提案手法全体としての性能評価を行う。 具体的には, WFG Test Suites を対象とした数值実験に より提案するアルゴリズムの得意・不得意な問題の調査 を行った. 以下, MOEA/D-DE に SPLASH を組み込ん だ手法を提案手法と呼ぶ.

2, 5, 8 目的の結果を表 2 から表 4 に示す. まず, WFG1 では, 全ての場合において提案手法の HV 值が勝っている. WFG1 は単峰性だが，偏りのある探索空間が探索の困難 性を引き起こす問題と考えられる [Huband 06]. このこと から, 提案手法は Tchebycheff 関数を採用した MOEA/DDE における偏りのある探索の弱点を緩和できていると 考えられる.

WFG4 は全ての場合において従来手法と比較して高い 性能を誇る. WFG4 は多峰性（ただし, 大域的には単峰 性）であり，局所解脱出メカニズムによって収束性能が 向上していると考えられる. 一方で WFG9 も多峰性問題 だが，2目的の場合において提案手法の性能は決して良 好でない. WFG9 は設計変数間に依存関係を持つ非分離 
表 1 WFG Test Suite の特性 [Huband 05]

\begin{tabular}{cc||cc|c|c}
\hline 問題 & 目的 & 分離可能性 & 景観 & 特徵 & パレートフロントの形状 \\
\hline WFG1 & $f_{1: M}$ & 分離可能 & 単峰性 & 偏り,フラットな領域 & 凸,複合 \\
WFG2 & $f_{1: M-1}$ & 非分離 & 単峰性 & & 凸,離散 \\
& $f_{M}$ & 非分離 & 多峰性 & & \\
WFG3 & $f_{1: M}$ & 非分離 & 単峰性 & & 線形,縮退 \\
WFG4 & $f_{1: M}$ & 分離可能 & 多峰性 & & 非凸 \\
WFG5 & $f_{1: M}$ & 分離可能 & 騙し & 非凸 \\
WFG6 & $f_{1: M}$ & 非分離 & 単峰性 & 非凸 \\
WFG7 & $f_{1: M}$ & 分離可能 & 単峰性 & 変数依存 & 非凸 \\
WFG8 & $f_{1: M}$ & 非分離 & 単峰性 & 変数依存 & 非凸 \\
WFG9 & $f_{1: M}$ & 非分離 & 多峰性, 騙し & 変数依存 & 非凸 \\
\hline
\end{tabular}

表 22 目的, 20 変数の $\mathrm{HV}$ 従来手法 提案手法

\begin{tabular}{lll}
\hline \hline WFG1 & 0.960 & $\mathbf{1 . 0 0 3}$ \\
WFG2 & $\mathbf{1 . 8 0 3}$ & 1.801 \\
WFG3 & $\mathbf{1 . 7 4 3}$ & 1.741 \\
WFG4 & 1.423 & $\mathbf{1 . 4 5 3}$ \\
WFG5 & $\mathbf{1 . 3 6 7}$ & $\mathbf{1 . 3 6 7}$ \\
WFG6 & 1.361 & $\mathbf{1 . 3 6 7}$ \\
WFG7 & $\mathbf{1 . 4 6 0}$ & $\mathbf{1 . 4 6 0}$ \\
WFG8 & $\mathbf{1 . 3 8 1}$ & 1.371 \\
WFG9 & $\mathbf{1 . 4 0 2}$ & 1.397 \\
\hline
\end{tabular}

表 35 目的, 20 変数の $\mathrm{HV}\left(\times 10^{1}\right)$ 従来手法 提案手法

\begin{tabular}{lcc}
\hline \hline WFG1 & 0.347 & $\mathbf{0 . 3 7 1}$ \\
WFG2 & 0.748 & $\mathbf{0 . 7 5 6}$ \\
WFG3 & 0.599 & $\mathbf{0 . 6 0 0}$ \\
WFG4 & 0.641 & $\mathbf{0 . 6 9 3}$ \\
WFG5 & 0.636 & $\mathbf{0 . 6 6 1}$ \\
WFG6 & 0.625 & $\mathbf{0 . 6 3 4}$ \\
WFG7 & 0.662 & $\mathbf{0 . 7 0 4}$ \\
WFG8 & 0.611 & $\mathbf{0 . 6 5 5}$ \\
WFG9 & 0.566 & $\mathbf{0 . 5 8 3}$ \\
\hline
\end{tabular}

表 48 目的, 20 変数の $\mathrm{HV}\left(\times 10^{2}\right)$ 従来手法 提案手法

\begin{tabular}{ccc}
\hline & 従来手法 & 提案手法 \\
\hline \hline WFG1 & 0.131 & $\mathbf{0 . 1 5 3}$ \\
WFG2 & 0.255 & $\mathbf{0 . 2 5 6}$ \\
WFG3 & $\mathbf{0 . 2 0 1}$ & $\mathbf{0 . 2 0 1}$ \\
WFG4 & 0.214 & $\mathbf{0 . 2 2 8}$ \\
WFG5 & 0.209 & $\mathbf{0 . 2 1 9}$ \\
WFG6 & 0.226 & $\mathbf{0 . 2 3 2}$ \\
WFG7 & 0.223 & $\mathbf{0 . 2 3 0}$ \\
WFG8 & 0.209 & $\mathbf{0 . 2 1 8}$ \\
WFG9 & 0.209 & $\mathbf{0 . 2 1 6}$ \\
\hline
\end{tabular}

問題であり, WFG8 も同様の傾向を示す.

全体を通してみると, 目的数が多くなるにつれて提案 手法の HV 值が高い傾向を示している.このことから, 提案手法は膨大な探索空間から探索履歴による有望領域 の推定によって，ある程度の探索空間の削減を行った効 果であると考えられる. また縮退したパレートフロント を持つWFG3 においては, 多数目的の場合でも従来手 法とほぼ同様の結果を示しており，実質的な探索空間の 少ない問題で提案手法が有効に働かない可能性が考えら れる。

結論として, 目的数が少ないなど，探索空間が広くな い問題や変数依存性のある非分離問題に対しては提案手 法は有効に㗢かない可能性を有することが分かった。

\section{5 実 験 2}

実験 2 では, 各メカニズムの探索へ与える効果, 影響 について考察する. 具体的には, 局所解脱出のみを組み 込んだ MOEA/D-DE（以下，脱出のみ），集中探索のみ を組み込んだ MOEA/D-DE（以下，集中のみ）を用いて， 単峰性問題であるWFG1, 多峰性問題であるWFG4, 変 数依存性を持ち非分離問題であるWFG8 に対して各メ カニズムの使用割合, HV の推移及び各メカニズムでの 更新率から有効性の検証を行った. なお, 脱出のみは提 案手法の集中探索部メカニズム部分を遺伝的操作で置換 したバージョンであり, 集中のみは提案手法の局所解脱
出メカニズム部分を遺伝的操作で置換したバージョンで ある。

図 5 に脱出のみの各メカニズムの推移を, 図 6 に集中 のみの各メカニズムの推移を示す. 図中の左縦軸が個体 であり, 横軸が世代数, 右縦軸が HV 值となっている. 赤, 緑, 黄の各グラフは, 各世代においてそれぞれのメ カニズムを適用した個体の数を表しており，左縦軸を参 照する．青のグラフは HV の推移を示し，右縦軸を参照 する。

例えば，図 5(a) における横軸の最終世代に着目すると， 約 130 個体が遺伝的操作を, 約 70 個体が局所解脱出を 行っており, HV は 1 付近の值であることが読み取れる.

図 5 より, 序盤（60世代付近）に局所解脱出メカニズ ムの割合がピークを迎え，以降は減少傾向にあることが 分かる.また，序盤の局所解脱出メカニズムの割合増加 と同時に, HV 值も大きく増加していることから, 局所 解脱出メカニズムは序盤に有効な手法であると推測され る. 次に図 6 より, 8 目的 WFG1, WFG4 においては最 終世代においても集中探索メカニズムの割合が多いこと が分かる．また序盤に集中探索メカニズムの割合がピー クを迎える傾向は局所解脱出メカニズムと同様だが，そ れ以降の減少が緩やかなことから, 集中探索メカニズム は中盤から終盤にかけて有効な手法であると推測される.

図 7 に提案手法の各メカニズムの推移を示す。また，表 5 に各メカニズムの使用数及び更新率（30 試行平均）を 
示す．まずWFG1 の場合（図 7(a)，(b)，(c)），2 目的の 場合では探索中盤から終盤にかけて遺伝的操作と局所解 脱出メカニズムの割合が同程度であるが，目的数が増え ると局所解脱出メカニズムの割合が遺伝的操作を上回っ ていることが分かる. 表 5 の解更新率からも， 2 目的の 場合に低かった局所解脱出メカニズムの更新率が 8 目的 では最も高くなっている.

次に WFG4 の場合（図 7(d)，(e)，(f)），探索中盤から 終盤にかけて遺伝的操作の割合が最も低く, 次いで局所 解脱出メカニズム, 集中探索メカニズムの順となってい る. この傾向は目的数が増えるに従い顕著になっており, 実際表 5 では, 2 目的の場合には大きな差がなかった更 新率が 5 目的, 8 目的では局所解脱出メカニズム及び集 中探索メカニズムでの更新率が遺伝的操作による更新率 を大幅に上回っている.

最後に WFG8 の場合（図 7(g)，(h)，(i)），5，8目的の 場合でも探索中盤から終盤にかけての各メカニズムの使 用割合はほぼ同じになっていることが分かる，表 5 によ ると, 局所解脱出メカニズムによる解更新率が全ての目 的で最も低く, その傾向は 8 目的の場合でも変化がない.

以上より, 局所解脱出メカニズムは目的数の多い問題 に対して有効だが，依存関係を持つ問題に対しては必ず しも有効でないことが分かった。また集中探索メカニズ ムは, 全ての問題に対してある程度の解更新率を期待で きることが確認できた.

\section{$5 \cdot 6$ 実 験 3}

実験 3 では, SPLASH のパラメータである $D$ 及び $K$ を変更した場合の性能の変化について WFG1, WFG4, WFG8 を用いて検証する.

はじめに, 表 6 に $D=2,5,25,50$ の場合の $\mathrm{HV}$ を 示す (集中探索に使用する領域数は $\lceil D / 5\rceil$ とした). 全 体的な傾向として, $D=50$ の場合に探索性能の向上が 見て取れる.一方で， 8 目的WFG1，5目的WFG8 のよ うに $D=2$ とした場合が最も有効な場合も存在することが 分かった。しかし, $D$ を大きくするにつれ，必要なメモ リ領域が膨大になる点，また計算時間も增加することか ら， $D$ は 25 から 50 の範囲で設定することを推奨する.

次に, 表 7 に $K=2,5,10,20$ の場合の HV を示す. 問題や目的によって適切な $K$ が異なるものの, それらの 差異は非常に小さい場合が多く, $K$ の值による探索性能 への影響は限定的であることが分かる.

\section{6. おわりに}

本稿では, MOEA に組み込むアルゴリズムとして，探 索履歴を利用した局所解脱出メカニズムと集中探索メ カニズム SPLASH を提案した. SPLASH を組み込んだ MOEA/D-DE と, 組み込んでいない MOEA/D-DE との 比較実験により, 提案手法が多峰性問題や目的数の多い
問題に対して有効であることが分かった。一方で, 変数 依存性のある非分離問題や目的数の少ない問題に対して は有効でない場合もある．また局所解脱出メカニズムは 中盤の探索の停滞時に探索の収束に貢献し, 集中探索メ カニズムは探索の終盤に効果的であることが分かった.

また，良好な領域が変数空間上のごく一部に限られて いる問題に対しては, 等分割による離散化手法が有効に 働かない可能性があるため, 今後はより効果的な離散化 手法の検討及び不得意な問題に対して効果的なメカニズ ムの検討を行う予定である.

\section{謝}

本研究は, 北海道大学情報基盤センター共同研究採択課 題であり, JSPS 科研費 26330269, 26350431, 16K00312 の助成を受けたものである.

\section{$\diamond$ 参 考 文 献}

[Alhindi 14] Alhindi, A. and Zhang, Q.: MOEA/D with Tabu Search for multiobjective permutation flow shop scheduling problems, 2014 IEEE Congress on Evolutionary Computation (CEC), pp. 1155-1164 (2014)

[Bandyopadhyay 08] Bandyopadhyay, S., Saha, S., Maulik, U., and Deb, K.: A simulated annealing-based multiobjective optimization algorithm: AMOSA, IEEE Trans. on Evolutionary Computation, Vol. 12, No. 3, pp. 269-283 (2008)

[Barbulescu 00] Barbulescu, L., Watson, paul J., and Whitley, L. D.: Dynamic representations and escaping local optima: Improving genetic algorithms and local search, AAAI/IAAI, pp. 879-884 (2000)

[Coello 04] Coello, C. A. C. and Lamont, G. B.: Applications of Multi-Objective Evolutionary Algorithms, World Scientific, Singapore (2004)

[Deb 95] Deb, K. and Agrawal, R.: Simulated binary crossover for continuous search space, Complex Systems, Vol. 9, No. 2, pp. 115148 (1995)

[Deb 96] Deb, K. and Goyal, M.: A combined genetic adaptive search (GeneAS) for engineering design, Computer Science and Informatics, Vol. 26, pp. 30-45 (1996)

[Deb 01] Deb, K.: Multi-Objective Optimization using Evolutionary Algorithms, Chichester, UK:Wiley (2001)

[堀野 12] 堀野将晴, 佐藤宽之 : 集約関数の探索履歴を用いた交叉 法による進化型多数目的最適化, 進化計算学会 進化計算シンポ ジウム 2012 講演論文集, pp. 424-430 (2012)

[Hornby 06] Hornby, G. S.: ALPS: The age-layered population structure for reducing the problem of premature convergence, Proceedings of the 8th Annual Conference on Genetic and Evolutionary Computation (GECCO '06), pp. 815-822 (2006)

[Huband 05] Huband, S., Barone, L., While, L., and Hingston, P.: A scalable multi-objective test problem toolkit, Evolutionary MultiCriterion Optimization (EMO 2005), pp. 280-295 (2005)

[Huband 06] Huband, S., Hingston, P., Barone, L., and While, L.: A review of multiobjective test problems and a scalable test problem toolkit, IEEE Trans. on Evolutionary Computation, Vol. 10, No. 5, pp. 477-506 (2006)

[Ishibuchi 98] Ishibuchi, H. and Murata, T.: A multi-objective genetic local search algorithm and its application to flowshop scheduling, IEEE Trans. on Systems, Man, and Cybernetics, Part C (Applications and Reviews), Vol. 28, No. 3, pp. 392-403 (1998)

[Ishibuchi 16] Ishibuchi, H., Masuda, H., and Nojima, Y.: Pareto fronts of many-objective degenerate test problems, IEEE Trans. on Evolutionary Computation, Vol. 20, No. 5, pp. 807-813 (2016)

[Jaeggi 08] Jaeggi, D., Parks, G., Kipouros, T., and Clarkson, P.: The development of a multi-objective Tabu Search algorithm for continuous optimisation problems, European Journal of Operational Re- 
search, Vol. 185, pp. 1192-1212 (2008)

[金田 13] 金田行雄 : 超多自由度系の最適化, Optimization of Systems with Ultra Many Degree of Freedom, 共立出版, 東京, Japan (2013)

[Knowles 00] Knowles, J. D. and Corne, D. W.: M-PAES: A memetic algorithm for multiobjective optimization, Proc. of 2000 IEEE Congress on Evolutionary Computation (CEC), Vol. 1, pp. 325-332 vol.1 (2000)

[Li 09] Li, H. and Zhang, Q.: Multiobjective optimization problems with complicated Pareto sets, MOEA/D and NSGA-II, IEEE Trans. on Evolutionary Computation, Vol. 12, No. 2, pp. 284-302 (2009)

[Martínez 13] Martínez, S. Z. and Coello, C. A. C.: A hybridization of MOEA/D with the nonlinear simplex search algorithm, 2013 IEEE Symposium on Computational Intelligence in Multi-Criteria Decision-Making (MCDM 2013), pp. 48-55 (2013)

[Moscato 99] Moscato, P.: New ideas in optimization, chapter Memetic Algorithms: A Short Introduction, pp. 219-234, McGrawHill Ltd., UK, Maidenhead, UK, England (1999)

[Zhang 07] Zhang, Q. and Li, H.: MOEA/D: A multiobjective evolutionary algorithm based on decomposition, IEEE Trans. Evolutionary Computation, Vol. 11, No. 6, pp. 712-731 (2007)

[Zitzler 98] Zitzler, E. and Thiele, L.: Multiobjective optimization using evolutionary algorithms - A comparative case study, Parallel Problem Solving from Nature - PPSN-V, pp. 292-301 (1998)

〔担当委員 : 小林 亮太〕

2016 年 11 月 01 日 受理

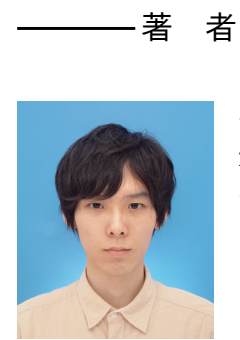

\section{者 紹 介}

\section{左文字}

2015 年室蘭工業大学情報電子工学系学科卒. 現在, 室蘭 工業大学大学院工学研究科博十前期課程在学中, 進化型多 目的最適化, 進化計算等の研究に従事. 情報処理北海道シ ンポジウム 2015 学術研究賞受賞.

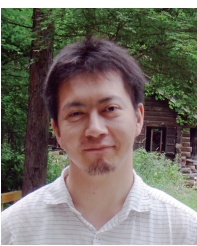

\section{渡邊＼cjkstart真也(正会員)}

2003 年同志社大学大学院工学研究科博士後期課程修了. 工学 (博士). 同年 产業総合研究所 生命情報科学研究セン ター特別研究員, 2004 年 立命館大学情報理工学部講師等 を得て現在 室蘭工業大学大学院しくみ情報系領域准教授. 進化計算, 最適設計, データマイニング等の研究に従事. 2005 年情報処理学会山下記念研究賞, 2009 年 IEEE CIS Japan Chapter Young Researcher Award 等受賞. IEEE, 情 報処理学会, 進化計算学会, 日本知能情報ファジィ学会, システム制御情報学会各会員. 


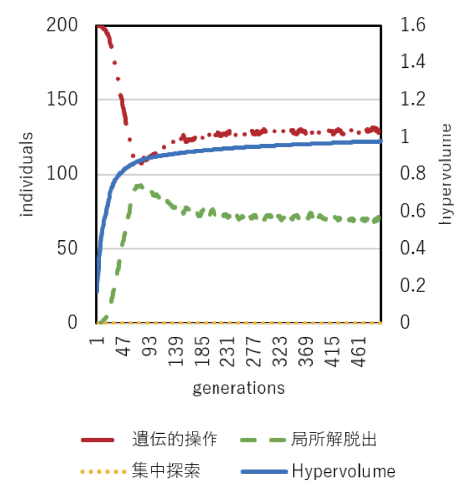

(a) 2 目的 WFG1

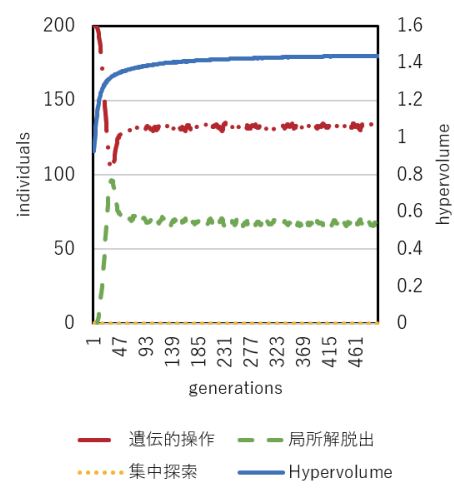

(d) 2 目的 WFG4

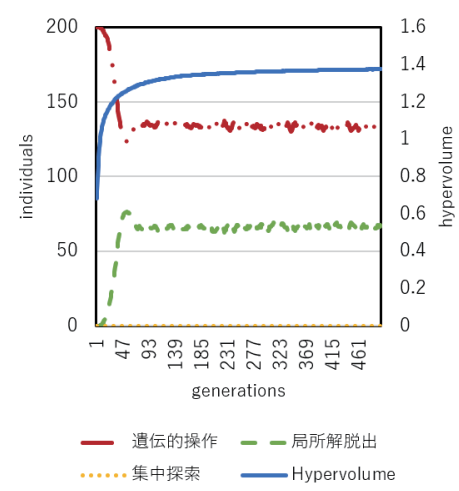

(g) 2 目的 WFG8

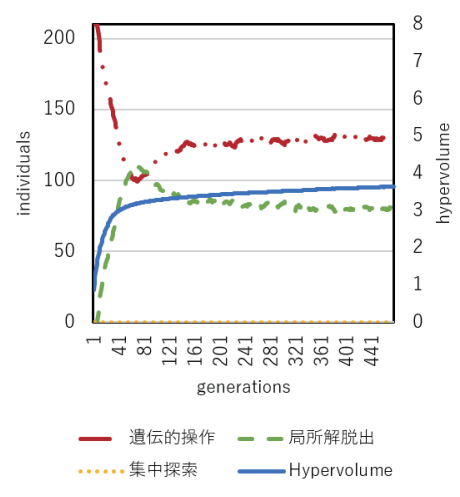

(b) 5 目的 WFG1

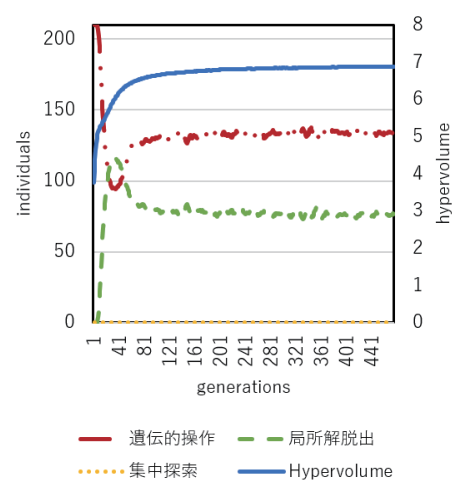

(e) 5 目的 WFG4

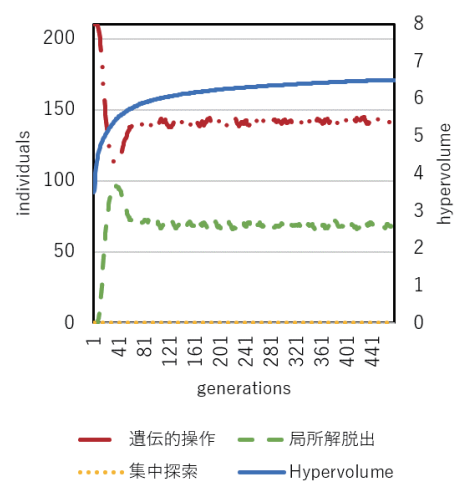

(h) 5 目的 WFG8

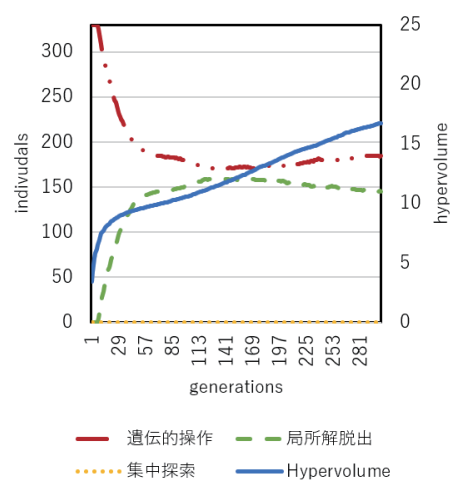

(c) 8 目的 WFG1

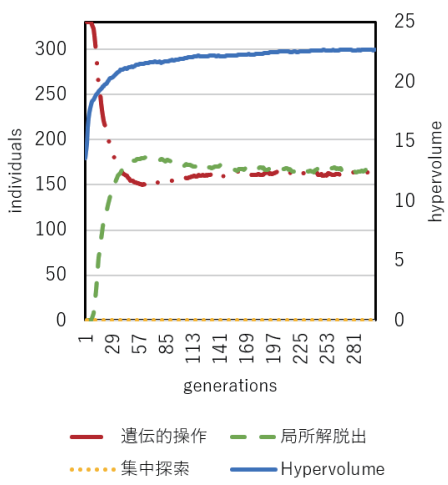

(f) 8 目的 WFG4

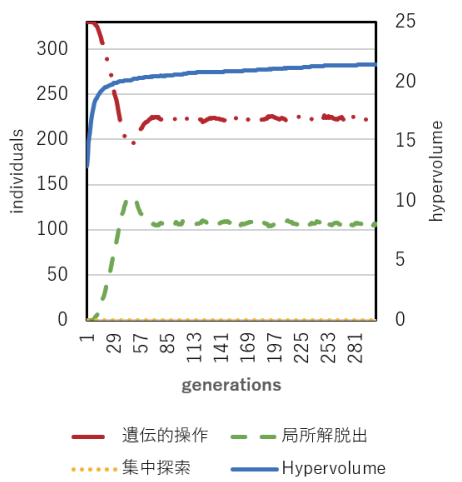

(i) 8 目的 WFG8

図 5 脱出のみにおけるメカニズム使用割合及び HV の推移

表 5 各メカニズムにおける解の更新率及び使用回数

\begin{tabular}{l|l|ccc|ccc|ccc}
\hline & & \multicolumn{3}{|c}{2 目的 } & \multicolumn{3}{c}{5 目的 } & \multicolumn{3}{c}{8 目的 } \\
\hline \hline \multirow{2}{*}{ WFG1 } & & 遺伝的 & 脱出 & 集中 & 遺伝的 & 脱出 & 集中 & 遺伝的 & 脱出 & 集中 \\
\hline \multirow{4}{*}{ WFG4 } & 使用数 & 34051 & 28718 & $\mathbf{3 7 0 3 1}$ & 31370 & 33684 & $\mathbf{3 4 7 3 6}$ & $\mathbf{3 7 8 6 4}$ & 35508 & 26297 \\
& 更新率 & $\mathbf{0 . 0 1 2}$ & 0.006 & 0.010 & 0.008 & 0.014 & $\mathbf{0 . 0 1 6}$ & 0.012 & $\mathbf{0 . 0 2 2}$ & 0.019 \\
& 使用数 & 33587 & 31195 & $\mathbf{3 5 0 1 9}$ & 30231 & 33854 & $\mathbf{3 5 7 0 6}$ & 26469 & $\mathbf{4 1 8 6 2}$ & 31339 \\
& 更新率 & 0.004 & 0.002 & $\mathbf{0 . 0 0 5}$ & 0.003 & 0.008 & $\mathbf{0 . 0 1 1}$ & 0.005 & 0.019 & $\mathbf{0 . 0 2 1}$ \\
& 使用数 & 34947 & 28099 & $\mathbf{3 6 7 5 3}$ & $\mathbf{3 4 8 2 5}$ & 31147 & 33818 & $\mathbf{3 9 6 7 7}$ & 30171 & 29822 \\
& 更新率 & $\mathbf{0 . 0 1 0}$ & 0.001 & 0.006 & 0.006 & 0.002 & $\mathbf{0 . 0 0 9}$ & $\mathbf{0 . 0 0 8}$ & 0.001 & 0.003 \\
\hline
\end{tabular}




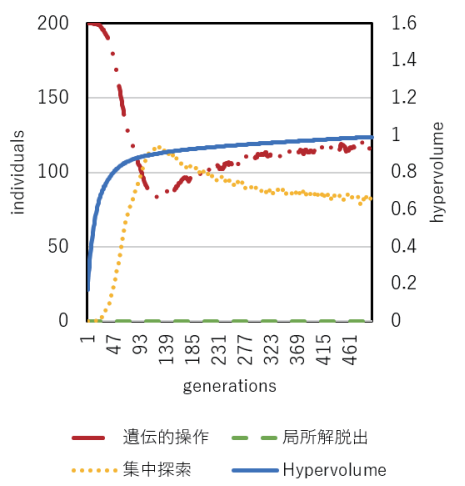

(a) 2 目的 WFG1

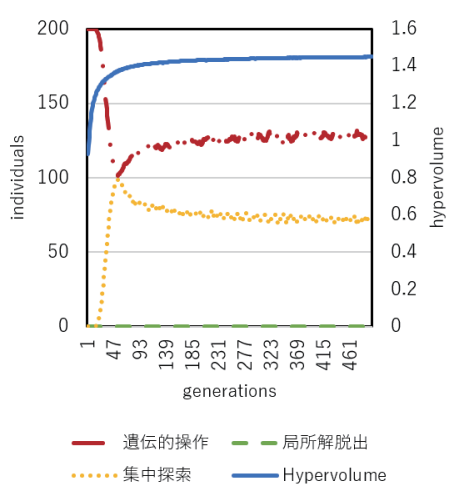

(d) 2 目的 WFG4

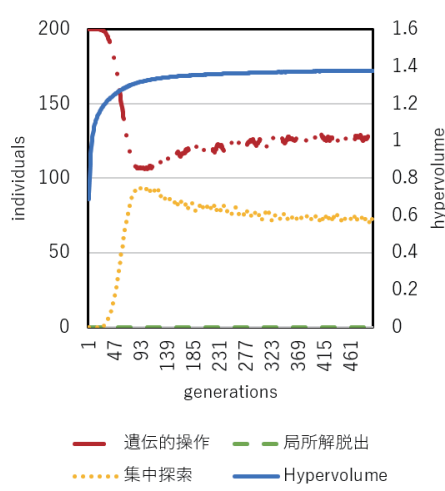

(g) 2 目的 WFG8

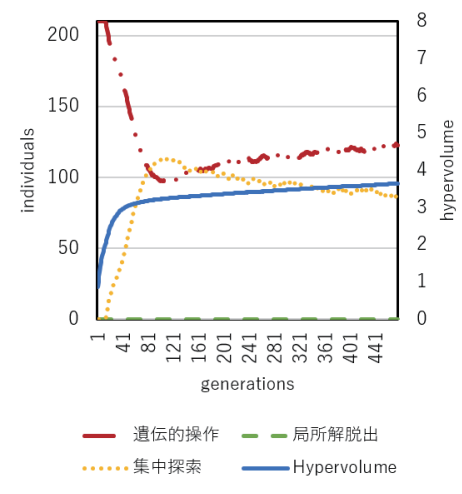

(b) 5 目的 WFG1

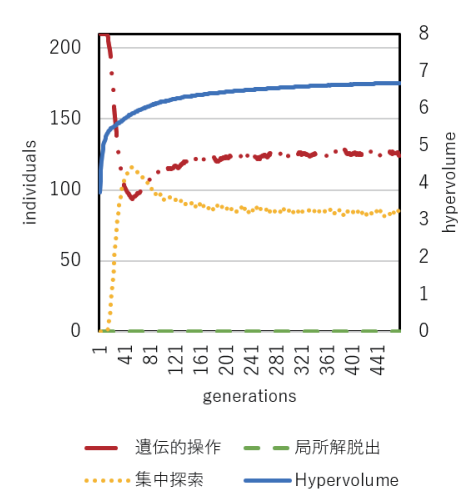

(e) 5 目的 WFG4

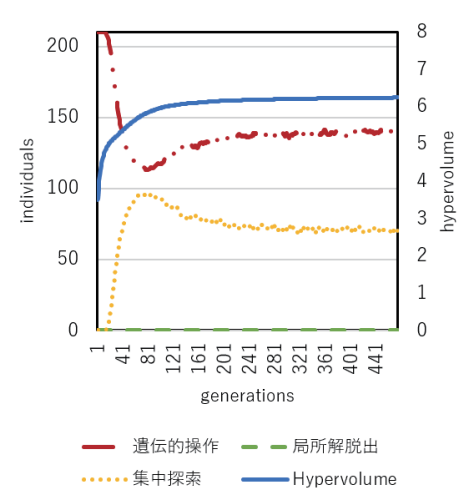

(h) 5 目的 WFG8

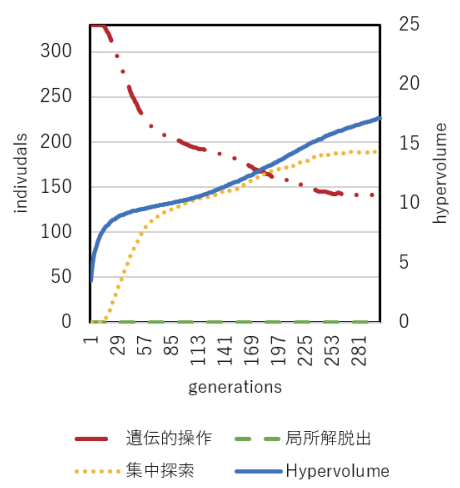

(c) 8 目的 WFG1

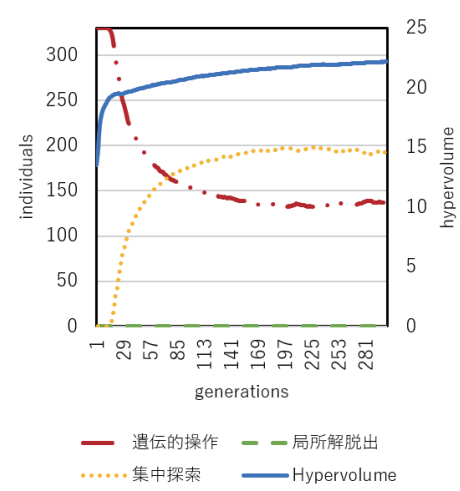

(f) 8 目的 WFG4

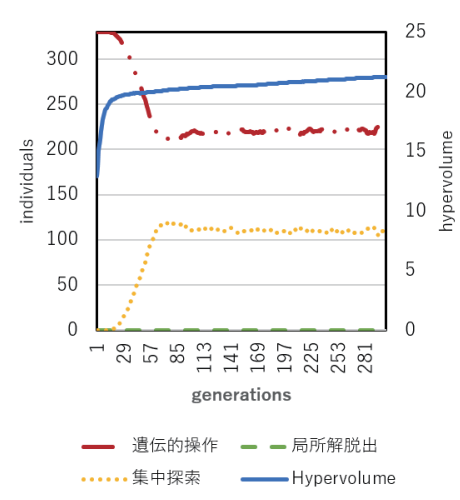

(i) 8 目的 WFG8

図 6 集中のみにおけるメカニズム使用割合及び HV の推移

表 6 D の変化による HV 值への影響 $(\mathrm{K}=5)$

\begin{tabular}{l|cccc|cccc|cccc}
\hline & \multicolumn{4}{|c}{2 目的 } & \multicolumn{4}{c}{5 目的 $\left(\times 10^{1}\right)$} & \multicolumn{4}{c}{8 目的 $\left(\times 10^{2}\right)$} \\
\hline & $D=2$ & $D=5$ & $D=25$ & $D=50$ & $D=2$ & $D=5$ & $D=25$ & $D=50$ & $D=2$ & $D=5$ & $D=25$ & $D=50$ \\
\hline \hline WFG1 & 0.967 & 0.972 & 0.995 & $\mathbf{1 . 0 0 3}$ & 0.356 & 0.361 & 0.367 & $\mathbf{0 . 3 7 1}$ & $\mathbf{0 . 1 5 4}$ & 0.149 & 0.147 & 0.153 \\
WFG4 & 1.443 & 1.447 & 1.451 & $\mathbf{1 . 4 5 3}$ & 0.685 & 0.689 & 0.692 & $\mathbf{0 . 6 9 3}$ & 0.226 & 0.225 & $\mathbf{0 . 2 2 8}$ & $\mathbf{0 . 2 2 8}$ \\
WFG8 & 1.368 & $\mathbf{1 . 3 7 1}$ & 1.370 & $\mathbf{1 . 3 7 1}$ & $\mathbf{0 . 6 5 6}$ & 0.654 & 0.655 & 0.655 & 0.216 & 0.214 & 0.216 & $\mathbf{0 . 2 1 8}$ \\
\hline
\end{tabular}

表 $7 K$ の変化による HV 值への影響 $(D=50)$

\begin{tabular}{l|cccc|cccc|cccc}
\hline & \multicolumn{4}{|c}{2 目的 } & \multicolumn{4}{c}{5 目的 $\left(\times 10^{1}\right)$} & \multicolumn{4}{c}{8 目的 $\left(\times 10^{2}\right)$} \\
\hline & $K=2$ & $K=5$ & $K=10$ & $K=20$ & $K=2$ & $K=5$ & $K=10$ & $K=20$ & $K=2$ & $K=5$ & $K=10$ & $K=20$ \\
\hline \hline WFG1 & $\mathbf{1 . 0 0 3}$ & $\mathbf{1 . 0 0 3}$ & 0.999 & 0.993 & 0.368 & $\mathbf{0 . 3 7 1}$ & $\mathbf{0 . 3 7 1}$ & 0.366 & 0.138 & 0.153 & $\mathbf{0 . 1 7 3}$ & 0.144 \\
WFG4 & 1.452 & $\mathbf{1 . 4 5 3}$ & $\mathbf{1 . 4 5 3}$ & 1.452 & 0.692 & 0.693 & 0.693 & $\mathbf{0 . 6 9 5}$ & 0.228 & 0.228 & $\mathbf{0 . 2 2 9}$ & 0.227 \\
WFG8 & 1.371 & 1.371 & 1.374 & $\mathbf{1 . 3 7 7}$ & 0.655 & 0.655 & 0.653 & $\mathbf{0 . 6 5 6}$ & 0.215 & $\mathbf{0 . 2 1 8}$ & 0.216 & 0.216 \\
\hline
\end{tabular}




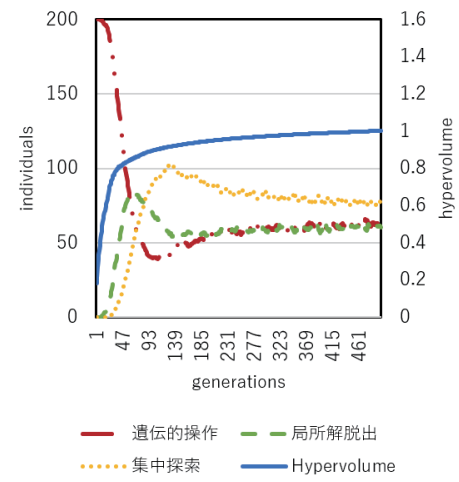

(a) 2 目的 WFG1

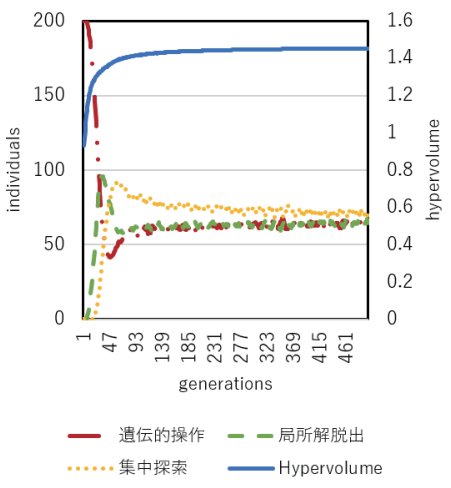

(d) 2 目的 WFG4

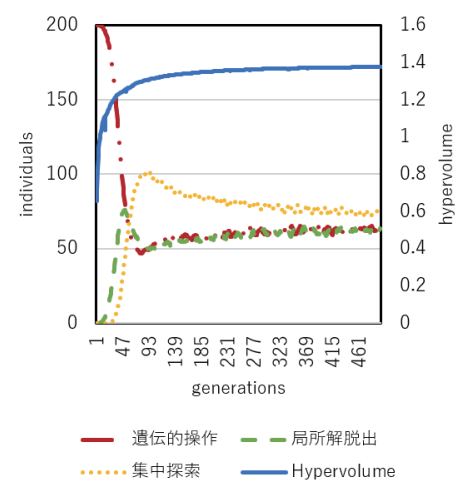

(g) 2 目的 WFG8

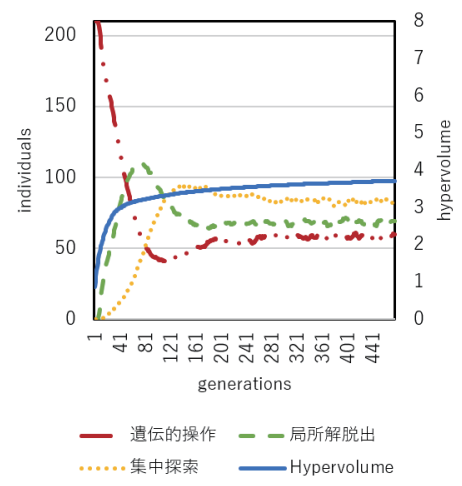

(b) 5 目的 WFG1

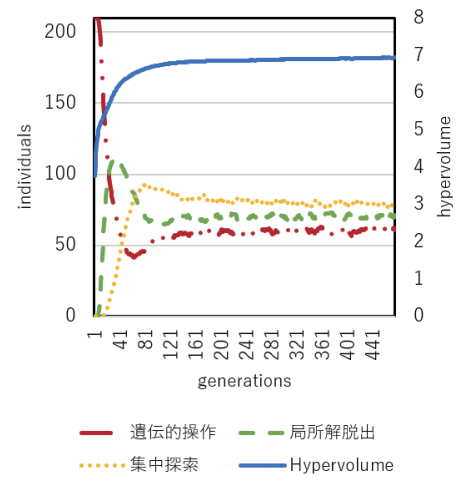

(e) 5 目的 WFG4

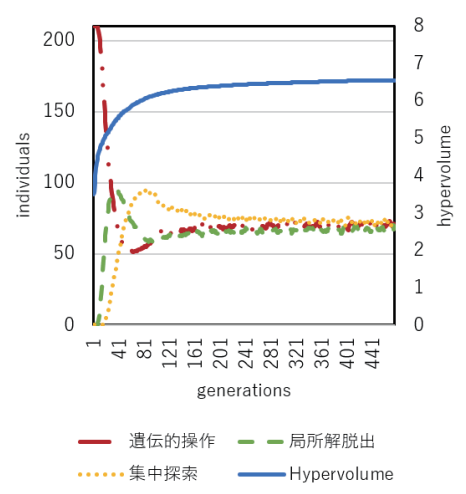

(h) 5 目的 WFG8

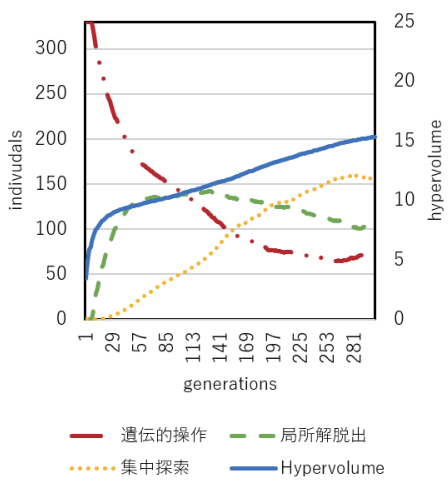

(c) 8 目的 WFG1

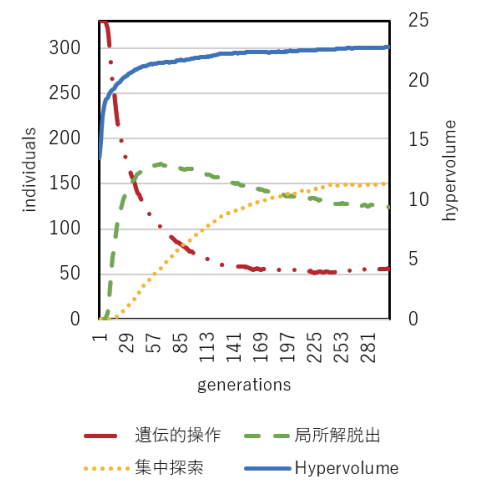

(f) 8 目的 WFG4

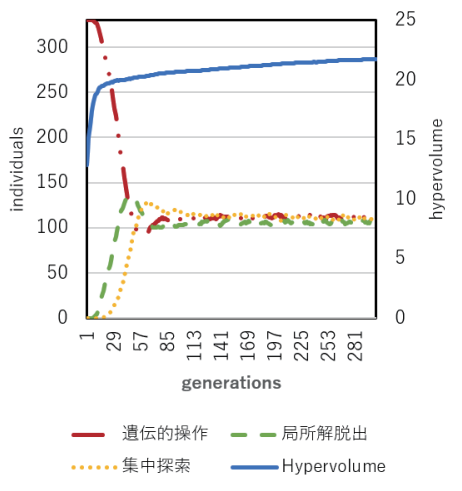

(i) 8 目的 WFG8

図 7 提案手法におけるメカニズム使用割合及び HV の推移 